\title{
Media Belajar Matematika Berbasis Multimedia Interaktif dengan Pendekatan Contextual Teaching and Learning
}

\author{
Lailatul Siamy ${ }^{*}$, Farida ${ }^{2}$, Muhamad Syazali ${ }^{2}$ \\ ${ }^{1}$ SMP Abdurrahman Auf. Jalan Ratu Dibalau No.68, Way Kandis, Tj. Senang, Bandar Lampung \\ 35131, Indonesia. \\ 2Universitas Islam Negeri Raden Intan Lampung. Jalan Endro Suratmin, Sukarame, Bandar \\ Lampung 35133, Indonesia. \\ * Corresponding Author. E-mail: lailatul.subandi24@gmail.com
}

Received : 16-11-2017; Revised : 07-01-2018; Accepted : 29-01-2018

\begin{abstract}
Abstrak
Tujuan dari penelitian ini adalah untuk mengetahui respon siswa dan para Ahli terhadap media pembelajaran berbasis multimedia interaktif dengan pendekatan contextual teaching and learning (CTL) pada materi bangun ruang yang telah dikembangkan. Metode dalam penelitian yang digunakan adalah 7 tahap dari 10 tahap metode pengembangan dan pengembangan dari Borg and Gall yang telah dimodifikasi oleh sugiyono. 7 tahapan itu yaitu potensi dan masalah, pengumpulan data, desain produk, validasi produk, perbaikan desain, uji coba produk, dan revisi produk. Instrument pengumpulan data yang digunakan adalah angket respon siswa dan validasi ahli materi. Berdasarkan analisis data yang diperoleh dari ahli materi dan ahli media dinyatakan bahwa media pembelajaran berbasis multimedia interaktif dengan pendekatan contextual teaching and learning (CTL) layak untuk digunakan, dan analisis data yang diperoleh dari siswa dinyatakan bahwa multimedia interaktif sangat baik. Hal ini berarti multimedia interaktif yang dikembangkan oleh peneliti dapat dimanfaatkan sebagai salah satu sumber belajar bagi siswa/i SMP/MTs kelas VIII.
\end{abstract}

Kata kunci: Media Pembelajaran, Multimedia Interaktif, contextual teaching and learning

\begin{abstract}
The purpose of this study is to determine the response of students and the experts to multimediabased interactive learning media with the approach of contextual teaching and learning (CTL) on wake-up space that has been developed. The method used in this research is 7 stages from 10 stages of development and development method from Borg and Gall which have been modified by sugiyono. The 7 stages are potential and problems, data collection, product design, product validation, design improvement, product testing and product revision. The instrument of data collection used is questionnaire of student response and material expert validation. Based on data analysis obtained from material experts and media experts stated that interactive multimediabased learning media with contextual teaching and learning approach (CTL) is feasible to use, and data analysis obtained from students stated that interactive multimedia is very good. This means that interactive multimedia developed by researchers can be used as a learning resource for students of SMP / MTs class VIII
\end{abstract}

Keywords: Learning Media, Interactive Multimedia, contextual teaching and learning (CTL)

\section{PENDAHULUAN}

Pendidikan proses belajar yang dilakukan secara berkesinambungan. Seiring berkembangnya teknologi secara langsung menuntut dunia pendidikan untuk menyesuaikan perkembangan tersebut dalam meningkatkan mutu pendidikan sehingga menciptakan sumber daya manusia yang berkualitas Pendidikan memegang peranan yang sangat penting untuk meningkatkan derajat kehidupan warga masyarakat dan derajat bangsa (Ditama, 2015). 
Dalam meningkatkan mutu pendidikan, khususnya mutu pendidikan matematika perlu di adakan terobosanterobosan baru, baik dalam pengembangan kurikulum, sumber daya manusia, inovasi pembelajaran, maupun dalam pemenuhan sarana dan prasarana pendidikan. Berkaitan dengan sumber daya manusia, guru matematika memegang peran penting dan sebagai ujung tombak dalam meningkatkan pemahaman matematika siswa. Salah satu cara untuk mencapai hasil belajar siswa yang optimal dalam pelajaran matematika jika para guru menguasai materi yang diajarkan dengan baik mampu memilih strategi atau metode pembelajaran dengan tepat dalam setiap proses pembelajaran (Khoirudin, Wahyuningsih, \& Rahardjo, 2013).

Kurang maksimalnya nilai peserta didik tersebut kemungkinan dikarenakan hanya pendidik dan buku teks yang dianggap sebagai pusat pembelajaran, dalam artian didalam penyampain ilmu pengetahuan hanya guru yang berperan aktif di dalam kelas (Permatasari \& Muslim, 2014). Akibat dari proses belajar mengajar yang belum terdapat variasi media, maka pelajaran matematika akan menjadi pelajaran yang membosankan. Sudirman dalam Alimudin (2015) mengatakan bahwa pemanfaatan media dalam pembelajaran mengakibatkan keinginan dan minat, memberikan semangat dan menimbulakan rasa ingin tahu siswa tinggi danbahkan berpengaruh secara psikologi kepada peserta didik. Berdasarkan pendapat diatas dapat disimpulkan bahwa media pembelajaran mempunyai fungsi yang sangat penting daalam proses belajar mengajar untuk meningkatkan mutu pendidikan.

Ditinjau dari proses pembelajaran matematika yang berlangsung selama ini didominasi dengan media cetak (buku) maupun papan tulis, dan tidak ada satupun pendidik yang memanfaatkan prasarana yang tersedia di sekolahan. Sehingga membuat minat dan motivasi belajar pesertadidik berkurang. Melihat tehnik cara pembelajaran yang terjadi, diduga penyebab siswa menganggap bahwa mata peleajaran matematika sulit dan membosankan. Dalam hal ini perlunya da terobosan-terobosan baru dalam proses pembelajaran. Sehingga siswa lebih termotivasi dalam belajar matematika.

Merujuk masalah diatas, penulis tertarik melakukan penelitian dengan mengembangkan media pembelajaran. Sehingga terciptanya pembelajaran yang aktif didalam kelas. Media pembelajaran interaktif adalah salah satu yang cocok untuk dikembangkan dan membuat siswa berinteraksi langsung dengan media (Meita, 2012). Berdasarkan penelitian sebelumnya bahwa media pembelajaran interaktif bisa membantu siswa lebih memahami materi yang diajarkan (Kartikasari \& Nugroho, 2012; Supriadi, 2015; Yuniati, Purnama, \& Nugroho, 2012).

Penelitian dengan mengembangkan media pembelajaran ini sengaja digunakan bantuan pendekatan kontekstual teaching and learning agar membedakan dengan penelitian sebelumnya. Selain itu strategi belajar mengajar CTL lebih menekankan kepada proses keterlibatan siswa secara penuh untuk dapat menemukan materi yang dipelajari dan menghubungkannya dengan situasi kehidupan nyata sehingga mendorong siswa untuk dapat menerapkannya dalam kehidupan mereka. Selain itu pengembangan media ini menggunakan multimedia interaktif, maka metode ini akan cocok disinergikan dengan media pembelajaran interaktif yang akan dikembangkan. 
Desimal, 1 (1), 2018 - 115

Lailatul Siamy, Farida, Muhamad Syazali

METODE

Jenis penelitian ini adalah penelitian dan pengembangan (RND). Prosedur yang digunakan dalam penelitian dan pengembangan ini adalah 7 tahap dari 10 tahap Borg and Gall yang sudah dimodifikasi oleh sugiyono. Tahapan itu dapat dilihat pada Gambar 1.

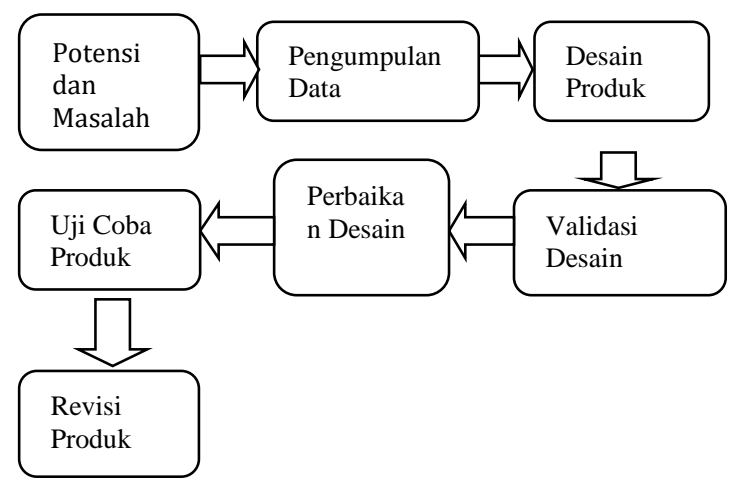

Gambar 1. Tahapan Pengembangan

Teknik pengumpulan data dalam penelitian ini adalah 1) Lembar Validasi, 2) Lembar Observasi, 3) Angket dan 4) Pedoman Wawancara. Rumus untuk menentukan jarak interval adalah sebagai berikut:

$$
\text { Skor Rata }- \text { rata }=\frac{\text { Jumlah } \text { skor }}{\text { jumlah butir }}
$$

\section{HASIL DAN PEMBAHASAN}

Penelitian ini dihasilkan produk berupa media pembelajaran berbasis multimedia interaktif dengan pendekatan CTL. Media Pembelajaran ini dikembangkan menggunakan prosedur penelitian dan pengembangan (Borg and Gall). menurut Brog and Gall, penelitian pengembangan ini dapat di sederhanakan sesuai kebutuhan. Penelitian ini disederhanakan sampai tujuh langkah penelitian dan pengembangan, hal ini selain karena keterbatasan waktu dan biaya, yakni sesuai dengan saran Brog and Gall yang dikutip dari Sutopo.
Validasi dilakukan oleh ahli materi dan ahli media

\section{a. Validasi ahli materi}

Validasi ahli materi bertujuan untuk menguji kelengkapan materi, kebenaran materi, dan sistematika materi, dilakukan dalam 2 tahap. Diperoleh hasil bahwa media pembelajaran layak dan siap digunakan dengan kriteria "sangat menarik", dapat dilihat pada Tabel 2.

Tabel 2 Hasil Validasi Ahli Materi

\begin{tabular}{ccc}
\hline Skor Rata - Rata & Kriteria & Keterangan \\
\hline 4,3 & Valid & Tidak Revisi \\
\hline
\end{tabular}

b. Validasi ahli media

Validasi ahli Media bertujuan untuk menguji kegrafikan dan dan penyajian pada media pembelajaran, dilakukan dalam 2 tahap. Diperoleh hasil bahwa media pembelajaran layak dan siap digunakan dengan kriteria "sangat menarik", dapat dilihat pada Tabel 3.

Tabel 3 Hasil Validasi Ahli Media

\begin{tabular}{ccc}
\hline Skor Rata - Rata & Kriteria & Keterangan \\
\hline 4,55 & Valid & Tidak Revisi \\
\hline
\end{tabular}

\section{c. Uji coba}

Hasil uji coba terkait kemenarikan dilakukan melalui dua tahapan yaitu uji kelompok kecil dan uji lapangan mengalami peningkatan rata-rata skor pada aspeknya, Perbandingan hasil uji coba dapat dilihat juga pada Tabel 4 . 
Desimal, 1 (1), 2018 - 116

Lailatul Siamy, Farida, Muhamad Syazali

Tabel 4 Hasil Uji Coba Kelompok Kecil

\begin{tabular}{cccc}
\hline Respon & $\begin{array}{c}\text { Jumlah } \\
\text { Skor }\end{array}$ & $\begin{array}{c}\text { Skor } \\
\text { Kelayakan }\end{array}$ & Kriteria \\
\hline 1 & 41 & 4.1 & $\mathrm{M}$ \\
2 & 41 & 4.1 & $\mathrm{M}$ \\
3 & 42 & 4.2 & $\mathrm{SM}$ \\
4 & 41 & 4.1 & $\mathrm{M}$ \\
5 & 43 & 4.3 & $\mathrm{SM}$ \\
6 & 43 & 4.3 & $\mathrm{SM}$ \\
7 & 43 & 4.3 & $\mathrm{SM}$ \\
8 & 42 & 4.2 & $\mathrm{SM}$ \\
9 & 43 & 4.3 & $\mathrm{SM}$ \\
10 & 41 & 4.1 & $\mathrm{M}$ \\
\hline Jumlah & $\mathbf{4 2 0}$ & $\mathbf{4 2}$ & $\bar{x}=\mathbf{4 . 2}$ \\
\hline
\end{tabular}

Tabel 5. Hasil Uji Coba Kelompok Besar

\begin{tabular}{|c|c|c|c|}
\hline Responden & $\begin{array}{l}\text { Jumlah } \\
\text { Skor }\end{array}$ & $\begin{array}{c}\text { Skor } \\
\text { Kelayakan }\end{array}$ & Kriteria \\
\hline 1 & 43 & 4.3 & SM \\
\hline 2 & 43 & 4.3 & SM \\
\hline 3 & 40 & 4.0 & $\mathrm{M}$ \\
\hline 4 & 44 & 4.4 & SM \\
\hline 5 & 43 & 4.3 & SM \\
\hline 6 & 42 & 4.2 & SM \\
\hline 7 & 43 & 4.3 & SM \\
\hline 8 & 44 & 4.4 & SM \\
\hline 9 & 43 & 4.3 & SM \\
\hline 10 & 41 & 4.1 & M \\
\hline 11 & 43 & 4.3 & SM \\
\hline 12 & 44 & 4.4 & SM \\
\hline 13 & 44 & 4.4 & SM \\
\hline 14 & 43 & 4.3 & SM \\
\hline 15 & 43 & 4.3 & SM \\
\hline 16 & 42 & 4.2 & SM \\
\hline 17 & 44 & 4.4 & SM \\
\hline 18 & 43 & 4.3 & SM \\
\hline 19 & 43 & 4.3 & SM \\
\hline 20 & 42 & 4.2 & SM \\
\hline 21 & 44 & 4.4 & SM \\
\hline 22 & 44 & 4.4 & SM \\
\hline 23 & 43 & 4.3 & SM \\
\hline 24 & 44 & 4.4 & SM \\
\hline Jumlah & 1.032 & 103.2 & $\bar{x}=4.3$ \\
\hline
\end{tabular}

Setelah dilakukan uji coba kelompok kecil dan uji coba kelompok besar untuk mengetahui kemenarikan media pembelajaran bebasis multimedia interaktif dengan pendekatan CTL pada materi bangun ruang, produk dikatakan kemenarikannya sangat tinggi sehingga tidak dilakukan uji coba ulang. Selanjutnya media pembelajaran dapat dimanfaatkan sebagai salah satu media belajar bagi peserta didik dan guru di SMP pada materi bangun ruang untuk kelas VIII. Penelitian ini sama dengan hasil penelitian sebelumnya bahwa media pembelajaaran interaktif dapat membantu meningkatkan motivasi siswa dalam belajar matematika (Giyoto \& Fauzi, 2013; Yuniati et al., 2012).

\section{SIMPULAN DAN SARAN}

Kesimpulan yang diperoleh dari penelitian dan pengembangan ini adalah Multimedia interaktif dengan pendekatan CTL yang dikembangkan dengan Brog and Gall yang dimodifikasi oleh sugiyono dinyatakan layak oleh ahli materi dan ahli media. Ditinjau dari Respon siswa terhadap multimedia interaktif yang dikembangkan mengggunakan pendekatan CTL memperoleh kriteria "sangat menarik".

Berdasarkan kesimpulan diatas maka penulis menyarankan bahwa penggunaan media pembelajaran interaktif sangat membantu siswa dalam belajar matematika terutama pendekatan siswa dengan materi pembelajaran sehingga siswa termotivasi dalam belajar matematika. Berdasarkan hal ini penulis menyarankan para guru menggunakan media pembelajaran interaktif dlam pembelajaran matematika. Untuk peneliti selanjutnya dapat dikembangkan pada materi lain atau mata pelajara lain.

\section{DAFTAR PUSTAKA}

Alimudin, A. (2015). Strategi pengembangan minat wirausaha melalui proses pembelajaran. $E$ - 
Desimal, 1 (1), 2018 - 117

Lailatul Siamy, Farida, Muhamad Syazali

Jurnal Manajemen Kinerja, 1(1), 113.

Ditama, V. (2015). Pengembangan Multimedia Interaktif dengan Menggunakan Program Adobe Flash untuk Pembelajaran Materi Hidrolisis Garam SMA Kelas XI (PhD Thesis). Universitas Sebelas Maret.

Giyoto, G., \& Fauzi, M. (2013). Metode Pembelajaran Bahasa Interaktif. IAIN Surakarta.

Kartikasari, D., \& Nugroho, G. K. (2012). Media Pembelajaran Interaktif Mata Pelajaran Bahasa Jawa Pokok Bahasan Aksara Jawa Pada Sekolah Menengah Pertama Negeri 2 Tawangsari Kabupaten Sukoharjo. Speed-Sentra Penelitian Engineering Dan Edukasi, 2(3).

Khoirudin, N., Wahyuningsih, D., \& Rahardjo,

D. $\mathrm{T}$. (2013). Pengembangan Media Pembelajaran dengan Menggunakan Aplikasi Mindjet MindManager 9 untuk Siswa SMA pada Pokok Bahasan Alat Optik. Jurnal Pendidikan Fisika, 1(1).

Meita, F. (2012). Pengembangan Media Pembelajaran Logika Berbasis Multimedia Interaktif untuk Siswa SMA Kelas X Sebagai Sumber Belajar Mandiri (PhD Thesis). UNIVERSITAS NEGERI YOGYAKARTA.

Permatasari, S. W. E., \& Muslim, S. (2014). Implementasi Model Pembelajaran Contextual Teaching and Learning (CTL) Pada Standar Kompetensi Dasar Memasang Instalasi Penerangan Listrik di SMKN 7 Surabaya. Jurnal Pendidikan Teknik Elektro, 3(2), 47-53.

Supriadi, N. (2015). Mengembangkan Kemampuan Koneksi Matematis Melalui Buku Ajar Elektronik Interaktif (BAEI) yang Terintegrasi Nilai-Nilai Keislaman. Al-Jabar: Jurnal Pendidikan Matematika, 6(1), 63-73.

Yuniati, N., Purnama, B. E., \& Nugroho, G. K. (2012). Pembuatan Media
Pembelajaran Interaktif Ilmu Pengetahuan Alam Pada Sekolah Dasar Negeri Kroyo 1 Sragen. SpeedSentra Penelitian Engineering Dan Edukasi, 3(4). 